\section{AMERTCAN NOTES}

WE are again indebted to the early sheets of Harper's Weekly for the following :-At a late meeting of the Boston Society of Natural History a communication was presented by Count Pourtales in reference to the character of the sea bottom off the coast of the United States, south of Cape Hatteras, and based upon the researches of the Coast Survey. According to his statement, the principal constituent of the coast is silicious sand from the coastline to about the line of one hundred fathoms-a limit which coincides nearly with the inner edge of the Gulf Stream throughout the greater part of its course. Outside of this line is a whitish calcareous mud, containing globigerina, and extending probably over the greater part of the ocean. South of the Vineyard Islands, and to the eastern end of Long Island, the silicious sand is replaced by a kind of bluish mud, known as the Block Island soundings. A similar mud is found off Sandy Hook in a range of depressions known as mud holes, which form a leading mark by which to find the port of New York in thick weather. A few rocky patches are found east of the neighbourhood of New York, and a rocky bottom occurs, sparingly, near Cape Fear ; but otherwise the sand is pretty uniform, varying only in the size of its grain. On the inner edge of the Gulf Stream there is a deposit of greensand composed of the cast-off foraminifera. - According to late advices from Florida, Mr. N. H. Bisbop, whose visit to that State in the interest of natural history we have already referred to, has started off in his yacht on a cruise down the coast for the purpose of making collections of Florida birds, \&c. He hopes to penetrate into the Everglades and prosecute some inquiries in regard to certain species of birds said to occur there, and no where else in Florida. - We regret to have to record the death, at St. Paul, Minnesota, on the $13^{\text {th }}$ of December last, of Prof. William Chauvenet, formerly Chancellor of Washington University, St. Louis. This gentleman has long been known in American scientific circles for his attainment as a mathematician and astronomer; and the various works published by him have occupied a high position as text-books and manuals of instruction. For a time connected with the Naval Academy at Annapolis, he was subsequently elected Professor of Astronomy and Mathematics in Washington University, St. Louis, afterwards becoming Chancellor, and remaining there until i 869 . His death occurred in consequence of exhaustion of the nervous powers at the age of a little over fifty. - We regret to learn that in the course of a disastrous fire at Springfield, Illinois, on the 25 th of February, the collection of the Geological Survey of the State of Illinois was in large part either destroyed or greatly injured, especially the fossil plants. This loss is the more severe, as the collection in question contained one of the finest series of Carboniferous fossils in the country, and embraced a large number of types of new species described by Messrs. Worthen and Meek. This should be a warning to all who have charge of valuable natural history collections, to give themselves no rest until their treasures are secured in fire-proof buildings. - We recently called attention to the excessive degree of cold to which meteorological observers on Mount Washington have been subjected during the present winter. Since then still greater inclemency has been recorded, during which the thermometer was fifty degrees below zero, while the wind had a velocity of one hundred miles an hour.-We have already, in a previous number, referred to the examination of a locality in California, by Prof. Marsh's exploring party, where numerous fossil trees had previously been discovered; and we learn that a detailed report may be looked for in the April number of the Fournal of Science. The region in question is situated on a high, rocky ridge in Napa County, California, near Calistoga Hot Springs, and about ten miles from the summit of Mount St. Helena. The ridge itself belongs to the Coast Range series, and forms the division between the Napa and Santa Rosa valleys. It is about two thousand feet in height, and is composed of metamorphic rock of the cretaceous period, overlain unconformably by later tertiary strata, consisting of light-coloured, coarse sandstone, and beds of stratified volcanic ashes. A careful examination showed that the trees on thesurface of the ground had been weathered out of the volcanic tufa and sandstone, and consequently were of the Tertiary age ; and also that there remained still embedded in the volcanic tufa, \&c., an extensive forest of very large trees, stretching over a great area. Some of the trees were of great size, a portion of one having been traced for a length of sixty-three feet, with a diameter of seven feet near its smaller end. Another tree indicated an original diameter of not less than twelve feet. All were prostrate, and had apparently been thrown down by the volcanic current which covered them, Many were much decayed internally and worm-eaten before they were buried. All of the wood was silicified, probably by means of hot alkaline waters containing silica in solution - a frequent result of volcanic action. A careful examination of the wood obtained at this locality showed no essential difference in structure from that of the modern redwoods of California (of the genus Sequoia). No other fossils were met with, which rendered it somewhat difficult to fix the precise epoch ; but it is considered probable by the Professor that the trees belonged to the Pliocene period. The origin of the volcanic material which covered the forest could not be ascertained, although it was supposed to have been derived from Mount St. Helena, which is the nearest volcanic peak.

\section{IHE SCIENCE AND ART DEPARTMENT}

$\mathrm{W}$

$\mathrm{TH}$ reference to examinations in large towns, the Department had previously issued the following regulation:-" In large towns or populous districts where there are three or more schools, and where numerous examinations are to be held, the Science and Art Department may at its discretion require a special local secretary to be appointed to manage the whole of the examination business. The Department will correspond with him alone on all subjects connected with the examination. $\mathrm{He}$ will be allowed a fee of ten guineas, and an extra fee of half a guinea for each night on which an examination is held."

The Department has now determined to place the conduct of these examinations as far as possible in the hands of officers appointed by the School Boards with the approval of the Science and Art Department. In such cases the School Board would determine, in concert with an Inspector from the Science and Art Department, the centres at which the examinations were to be held. They would appoint officers, one of them as special local secretary, with such a staff of assistants as would secure the presence of at least two, or if the number of candidates were very large, more officers at each examination. The examination papers would be sent to the officers appointed by the School Boards as they are now to the Local Committees. While these officers would be responsible for the conduct of the examinations, it would be expected that a few members of each of the Local Committees would visit the examinations and satisfy themselves with regard to the pupils of the classes they superintend. The same payment will be made to the special local secretary appointed by the Board as is now made to the special local secretary elected by the Committees ; and they would make a payment to each assistant of ros. for each night he was required to attend.

With regard to the number of Science Schools in which no fees are charged, or in which they are merely nominal, the Department thinks that the schools cannot be considered in a wholesome condition when students, a very large proportion of whom are adults in the receipt of wages, obtain their instruction wholly at the cost of the State and without any pecuniary contribution on their part. Nor is it probable that they will value as they ought what is given gratuitously. The directions in the Science Directory are very plain on the point. They state that "the payment of fees by the students can be looked upon as the only solid and sufficient basis on which a self-supporting system can be established and supported. Though the Department does not consider it necessary at present to lay down any rules making the payment of fees an absolute condition of the grants on account of Science instruction, yet as the payments from the State must be expected to diminish, and as aid on account of those persons who do nothing for themselves cannot be justified, committees of schools and classes and teachers are strongly urged (should it at present not be the practice) at once to impose as high a scale of fees as they consider can be raised not only on middle class students but also 
on artisans." The Department desires to call the serious aitention of the Committees of Schools to this instruction where fees are not imposed. They find that in some places not only is there an enire absence of fees, tut that there has even been an unseemly competition on the part of teachers to get students by any means to join their classes with a view of earning the payments on results. They therefore give notice to the Committees of Schools that unless they themselves take steps to remedy the present eviis by imposing at least sonie small fees, which should be paid to the Committee direct, it will be necessary to reduce the amount of the payments on results. They have no wish to reduce the piyments on results at present, and they would avoid as long as possible the imposition of new conditions which necessarily complicate the system of aid, and render the rules burdensome and difficult to work under, but the want of prorer vigilance on the part of the Committees may render this step necessary.

\section{AUGUSTUS DE MORGAN}

$\mathrm{T}^{\mathrm{H}}$ OSE readers of NATURE who are in the habit of examining the obituary column of the Times, will have regretted to see, on Monday morning last, the announcement of the death of the eminent mathematician, Augustus De lilorgan. He had been seriously ill for the past two years. A disease of the kidneys, complicuted with other disorders, had reduced him to a shadow of his former self, and rendered him incapable of any protract:d exertion. This was the more trying as his mind retained all its former energy, and the doctors forbade his rearling more than an hour or two in the day. He was, however, allowed to see his friends, and often amused and irstructed them by the hour together from the stores of his extraordinary memory. During the last few weeks he had become considerably weaker, and on Saturday the $18 \mathrm{th}$, at one o'clock in the afternoon, his spirit was released from the body which for so many months had been orily a burden to it.

Augustus De Morgan was the son of a Colonel in the Madras army. He could trace his descent from the mathematician, James Dodson, author of the "Anti-Logarithmic Canon." He was born in the summer of 1806 , in Southern India. While yet a school-boy, he showed his taste for mathematics by filing thick notebooks with "infinite series," which he interspersed with grotesque figures and quaint faces. In 1823 he went to Cambridge, where he entered at Trinity College; his rooms were in the south-east comer of the great court, then called "Mutton Hole Conner," which he affirmed was a contraction from Merton Hall Corner.

In the tripos of 1827 he was Fourth Wrangler, but he never proceeded to the degree of M.A., owing to his objection to subscribe to the tests, and it is sad to think that the same conscientious scruples debarred this iilustrious man from a Fellowship. On leaving Cambridge he entered at Lincoln's Inn, and would have forsaken Mathematics for the study of the Law, but that in 1828 , the London University, now University College, was founded, and he was offered the Professorship of Mathematics there, which he accepted, and remained a firm supporter of the College and its principle of no tests till the year 1866 , when the Ccuncil, in making an appointment to the chair of Logic arid Mental Phi osophy, refused, as the Professor believed, one of the candidates in account of his religious opinions. Prof. De Morgan remon. sirated, Lut his remonstrarces weie disreyarded. He then thought it his duty to inform them that he must forsake the College if the College forscok its principles. But the Council turned a deaf ear; and Prof. de Morgan who had for nearly forty years been the chief honour and orrament of their institution, left them, and, we are informed, nerce afterwards entered the ir gates.
To Estimate the energy of the Prufessor we must lock at him rot only as a tcach:r of mathematics, but as a mathematician, an actuary, a logician, an historian, a biographer, aud a bibliophile. First, then, as a teacher of mathematics perhaps nomin has been more successful in training distinguished mathematicians. Amongst the latter we may mention the names of Prof. Clifton, Judge Hargreave, Mr. Routh, and Mr. Todhunter. Prof. Sylvester a!so attended his leciures, though the rclationship of professor and pupil did not in this case last very long. He had a method of intcresting his hearers in the subjects on which he lectured, and of making them love mathematics forits own sake, which few othermen haveever attained tc. He expended a great deal of work upon his classes. The subject-matter of tvery lecture which he delivered was entered in a note-book and sent into the library of the college for the beneft of his pupils while writing out and expanding their own notes.

As a mathematician, his work was so various that it is difficult for aby one man to review it, and it would be out of place to attempt anjthing of the kind here; but we may allude in passing to his double algebra, which was $c$ si tainly the for erunner of Quarternions, and contained the geometrical interpretation of the symbol $\sqrt{-1}$. Sir W. R. I ism.iton, in the preface to his Leciures on Quaternions, p. 4I, says, "I3ut I wish to mention that among the circumstances which assisted to prevent me from losing sigit of the general subjects, and from wholly abandonin: the attempt to turn to some useful account those early speculaticn; of mine, on triplets and on sets, was probibly ti.e pullication of Prof. De Morgan's first paper on the 'Foundation of Algebra,' of which lie sent me a copy in 1041. ."

As a writer of mathematical text books, he tcok the highest rink, his books being more suitable, l. owever, for teachers than for pupils. They were characterised by extreme clearness, exhaustiven ss, and sugyestiveness. Perhaps those best known are his "Elements of Atithmetic," published I $83^{\circ}$; his " Elemonts of Alg tbra," pub. lished 1835 ; and his "Differential and Intersial Ca:culuc, with elementary illustrations," which i i a pirf ct mine of original thought, and in which sone of tie most important extensions which the subject has since receive. tinctly indicated, and it was published by the socicty for the Diffision of Useful Knowledge.

As an actuary he occupied the first place, though he was not directly associated with any particular office, but his opinion was sought for on all sides, by actuaries, on questions connected with the theory of yrobabiities as applied to life contingencies. In 1838 he wrote his "Essay on Probabilities," which still retains a high place among the literature of insurance offices.

As a logician he was well known, and his "Formal Logic," together with the Treatise of Mr. Boole, may be said to have created a new era in logical science. His controversy with Sir William Hamilton will long be remembered.

As an historian and biographer, the Engiish Encyclopadia says of him that "he had a great affection for, and an extensive and minute erudition in, all kinds of literary history, biography, and antiquities." He was one of the most extensive contributors to the Penny Cyclopadia. many of the articles of scientific biography having been written by him, as well as most of the mathematical and astronomical articles. The lives of Newton and Halley in Knight's "British Worthies," were also from his pen.

As a bibliophile, his "Arithmetical Books from the Invention of Printing to the Present Time, 1847 ," and his "Budget of Paradoxes" will long remain celebrated. $\mathrm{He}$ was the possessor of a very large collection of old mathematical works.

In addition to this the Professor contributed largely to the Philosophical Magraine, the North British Reviezt, the Athenaum, and the Transactions of the Cambridge Philoscphical Society, in which he publiched most of his 